Research Article

\title{
Eco-friendly approach to control dengue vector Aedes aegypti larvae with their enzyme modulation by Lumnitzera racemosa fabricated zinc oxide nanorods
}

\author{
Pratik P. Dhavan ${ }^{1}$ (D) B Bhaskar L. Jadhav ${ }^{1}$ (D)
}

Received: 8 December 2019 / Accepted: 30 March 2020 / Published online: 7 April 2020

(c) Springer Nature Switzerland AG 2020

\begin{abstract}
Aedes aegypti mosquito species is a primary vector for dengue, chikungunya and Zika infections, and vector control is the only key approach for reducing their transmission. The present study emphasizes on environmental friendly approach for the fabrication of zinc oxide nanorods ( $\mathrm{ZnO} N R s$ ) using aqueous extract of Lumnitzera racemosa flower buds (LB) as a reducing and stabilizing agent. ZnO NRs were examined by UV-Vis spectroscopy with characteristic absorbance band at $373.82 \mathrm{~nm}$ and bandgap of $3.25 \mathrm{eV}$. FT-IR analysis revealed the functional groups associated with ZnO NRs. The crystallinity of LB-ZnO NRs was further investigated using X-ray diffraction. The Zeta potential displayed a surface charge of $-23.5 \mathrm{mV}$ on NRs. Energy dispersive spectra analysis and SEM analysis confirmed the formation of ZnO NRs whilst TEM highlighted the average length and diameter in the range of 250-300 $\mathrm{nm}$ and $45-50 \mathrm{~nm}$ respectively. LB-ZnO NRs were found to be efficacious against $A$ e. aegypti 4 th instar larvae with $\mathrm{LC}_{50}$ of $24.74 \mu \mathrm{g} / \mathrm{ml}$. Decreased acetylcholinesterase $(60.6 \%)$ and glutathione S-transferase (24.4\%) activities were also evaluated in Ae. aegypti larvae which were exposed to synthesized LB-ZnO NRs with no genetic aberrations. All these outcomes propose the potential employment of LB-ZnO NRs in mosquito control, as well as an effective alternative to insecticide resistance.
\end{abstract}

\section{Graphical abstract}

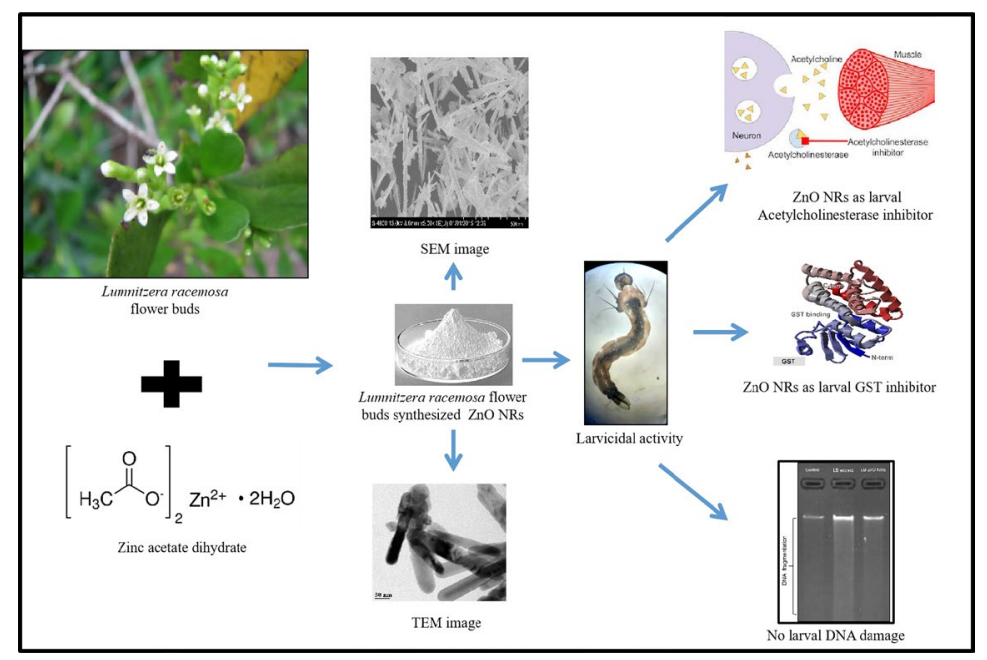

Pratik P. Dhavan, pratik.dhavan11@gmail.com; Bhaskar L. Jadhav, drbljadhav@gmail.com | 1 Department of Life Sciences, University of Mumbai, Vidyanagari campus, Santacruz (East), Mumbai 400098, India. 
Keywords Aedes aegypti - Green synthesis · Lumnitzera racemosa $\cdot \mathrm{ZnO}$ nanorods · Mosquito-larvicidal

\section{Introduction}

Arthropods are hazardous vectors that could influence the growing global human and animal population as epidemics and pandemics of lethal pathogens [1]. The most important threats faced by mosquitoes worldwide are those (Diptera: Culicidae), which are the vectors of important diseases such as yellow fever, Western Nile virus (WNV), dengue, malaria and filariasis. Millions of individuals globally are at risk and endangering life due to mosquito-borne illnesses, and have such a heavy public health burden that they are blamed on continuous continental underdevelopment [2].

The knowledge about ecology and the control of mosquitoes is of crucial importance in the sense of integrated vector management, to combat the spread of many mosquito-borne diseases [3, 4]. Ae. aegypti (Linnaeus) is the primary dengue and Zika vector, a cosmotropic species. As a vector of dengue fever and chikungunya in India, this species is particularly dangerous because the number of dengue fever instances has increased substantially over the past years $[1,5,6]$. Chemical insecticides used for regulating mosquitoes which are detrimental to human health and non-target organisms. Moreover, mosquito vectors have developed resistance towards the synthetic insecticides, namely temephos by carrying genes that encode acetylcholinesterases (AChE). AChE enzyme breaks down acetylcholine which carries the transmission of nerve impulses through the synaptic gap and acts as a primary target for synthetic insecticides [7]. Besides, a detoxifying enzyme such as Glutathione S-transferase (GST) is also expressed by insects which helps to neutralize the toxicity of different xenobiotics [8]. On these grounds, newly implemented eco-friendly methods have been used to improve mosquito vector control [9]. Young mosquito instars have shown decreased mobility and are therefore often easy to target. Thus mosquitoes can be killed before dispersing to human dwellings by targeting at their larval stages [10].

Plant materials showing mosquitocidal characteristics against major mosquito vectors have been recently emphasized. Many naturally occurring compounds isolated from plants exhibits excellent mosquito toxicants which act as ovicidal, pupicidal, adult repellents, growth and/or breeding inhibitors [11]. Lumnitzera racemosa Willd. (Combretaceae) is a true mangrove found along the coast of Asia. Due to the high calorific value, the wood of $L$. racemosa is used as a fuel, while its leaves are eaten on South Pacific Island all through periods of scarcity by herbivores [12]. Besides, the reddish bark contains $\sim 15 \times 19 \%$ tannins used in leather industries. Moreover, fluid extracted from the stem of this plant were found effective in treating itches and herpes when applied externally. The most important secondary metabolites of $L$. racemosa are flavonoids, triterpenoids, tannins, fatty acids and polyisoprenoid alcohols [13]. This plant exerts numerous pharmacological activities, such as antibacterial [14], antifungal and antihypertensive [15], protein tyrosine phosphatase 1B (PTP1B) inhibitory, hepatoprotective and antioxidant activities [16]. While recent studies revelled $L$. racemosa leaves to be toxic against larvae of $A$. aegypti [17].

Green technologies have recently been shown to be a new strategy for reducing the use of chemical pesticides since overuse has often led to massive non-target impacts and widespread resistance $[9,18]$. Modern study has revealed an increased level of insecticide activity in green nanoparticles (NPs) synthesized by Euphorbia rothiana [19], Cymbopogon citratus [20], Pedalium murex [21] etc. Among different NPs, Zinc Oxide nanoparticles ( $\mathrm{ZnO}$ NPs), having nanosized morphology, have increased interest among several researchers as a result of their exclusive optical or chemical activities [22]. ZnO NPs have remarkable characteristics, including large binding energy, broad bandgap, and elevated piezoelectric characteristics [23]. It has various applications, including UV light-emitting diodes, laser diodes, and catalysts [24]. Also, ZnO NPs have a highly promising prospect for biological functions such as gene delivery [25], biological sensing and labelling [26], drug delivery and nanomedicine [27, 28], antibacterial [29], antifungal [30], along with larvicidal, acaricidal, pediculicidal activity [31].

The present study was thus focussed on ZnO Nanorods (ZnO NRs) synthesis with a single step procedure based on easy to obtain $L$. racemosa flower buds aqueous extract. LB-ZnO NRs were characterized using a variety of biophysical methods. Furthermore, larvicidal toxicity of LB extract and $\mathrm{LB}-\mathrm{ZnO}$ nanorods were evaluated on dengue vector Ae. aegypti and their enzyme modulation on AChE and GST enzymes were studied.

\section{Materials and methods}

\subsection{Materials and reagents}

Lumnitzera racemosa flower buds (LB) were collected from Bhatye beach area located at $16^{\circ} 58^{\prime} 44.0691^{\prime \prime} \mathrm{N}$ and 7317'38.7499" E. Ratnagiri District, Maharashtra, India and authenticated by an expert taxonomist. L. racemosa 
flower buds were washed thoroughly with tap water followed by distilled water to remove adhered particles. Flower buds were then kept for drying under the shade at room temperature $\left(27 \pm 2{ }^{\circ} \mathrm{C}\right)$. Water purified using Millipore Milli-Q $\left(18.2 \mathrm{M} \Omega . \mathrm{cm}\right.$ at $\left.25^{\circ} \mathrm{C}\right)$ purification system was used throughout the experiment. Acetylthiocholine iodide was purchased from Hi-Media (Mumbai, India), reduced glutathione (GSH), 1-chloro2,4-dinitrobenzene (CDNB), DTNB reagent (5,5'-dithiobis-2-nitrobenzoic acid), Zinc acetate dihydrate, Agarose, Ethylenediaminetetraacetic acid (EDTA) and ethidium bromide were purchased from Sigma-Aldrich, India. Proteinase $K$ and RNase A were procured from ThermoFisher Scientific, India.

\subsubsection{Preparation of $L$. racemosa flower buds extract}

Aqueous LB extract was prepared by adding $5 \mathrm{gm}$ plant powder in $100 \mathrm{ml}$ Milli-Q water (MQ-W) and placed in a water bath at $100^{\circ} \mathrm{C}$ for $20 \mathrm{~min}$. The obtained filtrate and residue were separated using Whatman filter paper No. 42 (42 ashless diameters $125 \mathrm{~mm}$ GE Healthcare Life Sciences). Filtrate solution thus obtained is filtered with a $0.2 \mu \mathrm{m}$ cellulose syringe filter (Rayna Biotech, UK) and stored in the refrigerator at $4{ }^{\circ} \mathrm{C}$ and was later used for the synthesis of ZnO NPs.

\subsubsection{Production of zinc oxide nanoparticles}

To $80 \mathrm{ml}$ of $10 \mathrm{mM}$ zinc acetate dihydrate, $20 \mathrm{ml}$ of obtained LB aqueous extract was added dropwise under constant stirring at room temperature. The resulting solution was then placed on a magnetic stirrer at $60^{\circ} \mathrm{C}$ until the off-white suspension of NPs were formed. The solution was then centrifuged at $3000 \mathrm{rpm}$ for $20 \mathrm{~min}$ and the residue was washed several times to remove any unreacted materials. The resulting supernatant was discarded, and the pellet was collected and placed in a furnace at $400^{\circ} \mathrm{C}$ to obtain the desired product in powder form.

\subsection{Characterization}

\subsubsection{UV-Vis spectroscopy (UV-Vis)}

Optical properties of nanoparticles were examined using UV-Vis spectroscopy. Absorption spectrum of ZnO NPs after $24 \mathrm{~h}$ was recorded using UV-Visible spectrometer Shimadzu, UV-1800 ( $\lambda=200-800 \mathrm{~nm})$ to confirm the synthesis of LB-ZnO NPs.

\subsubsection{Fourier transform infrared spectroscopy (FTIR)}

Different types of functional groups which are associated with the synthesis of NPs was confirmed through FTIR analysis. The dried powder of ZnO NPs was thoroughly mixed with potassium bromide $(\mathrm{KBr})(2: 98$ ratio $\mathrm{w} / \mathrm{w})$ and compressed at 11,000 psi to make the disc. The disk was then inserted into the FTIR spectrophotometer (Perkin Elmer Frontier, 91579) and the spectrum was recorded at the diffuse reflection mode at a resolution of $4 \mathrm{~cm}^{-1}$ in the test range of $500-4000 \mathrm{~cm}^{-1}$. A similar process with LB aqueous extract was also performed.

\subsubsection{X-ray diffraction (XRD)}

Crystalline nature of synthesized LB-ZnO NPs was recorded using XRD diffraction working at $40 \mathrm{kV}$ with a current of $40 \mathrm{~mA}, \mathrm{Cu}$ Ka radiation ( $1.54 \AA$ ) in a $\theta-2 \theta$ configuration using Bruker D8 Discover model (Bruker, Germany).

\subsubsection{Scanning electron microscopy (SEM) and Energy-dispersive spectra (EDS)}

Scanning electron microscopes (SEM) helps in the validation of NPs morphology. A few micrograms of LB-ZnO NPs were dropped on a carbon-coated copper grid for SEM analysis and the excess powder was discarded. The scanning electron microscopic images were then captured using JEOL System JSM-6390LV (Akishima, Tokyo, Japan) at an acceleration voltage of $15 \mathrm{kV}$. An energy dispersive spectrometer (EDS make FEl series Quanta 200 with EDS 3.0.13) at an energy range of $0-10 \mathrm{keV}$ was used to take energy dispersive spectra for LB-ZnO NPs.

\subsubsection{Zeta potential}

Zeta potential was performed to analyze charge on synthesized LB-ZnO NPs using Zetasizer (Nano series NanoZS90, Malvern Instruments).

\subsubsection{Transmission electron microscopy (TEM)}

On carbon-coated copper grids, powdered LB-ZnO NPs were mounted and transmission electron microscopy observations were carried out using FEI Tecnai G2, F30 system working at an accelerating voltage of $200 \mathrm{kV}$.

\subsection{Mosquito rearing and larvicidal activity}

The larvae of Ae. aegypti were collected from Vidyanagari campus, University of Mumbai, Kalina, Mumbai, and surrounding areas. Collected larvae were identified by Dr. Mira Ramaiya, Entomologist, Haffkine Institute For Training, Research And Testing, Parel, Mumbai. The larval colony was maintained in the lab at $28 \pm 1{ }^{\circ} \mathrm{C}$ with $80 \pm 5 \%$ relative humidity, and 14L:10D photoperiod [32]. Adults were fed with $2 \%$ sucrose solution soaked in non-absorbent cotton. 
Female mosquitoes were fed with periodic blood meals for egg maturation by the membrane feeding technique [33]. The eggs were collected on Whatman filter paper lined in the bowl and allowed to hatch in dechlorinated water. A 2:1 (w/w) mixture of yeast powder and dog biscuits were used to feed the larvae. The pupae formed were gathered and moved to glass cages for adult emergence. Laboratory colonies of mosquito larvae (F1 generation) were used for the larvicidal activity.

Larvicidal activity of LB aqueous extract and synthesized LB-ZnO NPs was carried out under the WHO standard method [34] as follows. Accordingly, LB extract and LB-ZnO NPs were dispersed in dechlorinated water to prepare a graded series of concentration $(500-2500 \mu \mathrm{g} / \mathrm{ml}$, for aqueous LB extract and $10-50 \mu \mathrm{g} / \mathrm{ml}$, for LB-ZnO NPs). Further, early 4th instar larvae of Ae. aegypti were transferred to $250 \mathrm{ml}$ plastic cups in batches of 20 each containing $199 \mathrm{ml}$ of distilled water and $1 \mathrm{ml}$ of respective treatment in the graded concentrations. Each experiment was conducted in triplicates along with a respective control group on three separate days to ensure reproducibility. The control group consisted of $200 \mathrm{ml}$ of distilled water only. No food was provided during the duration of the entire experiment. Symptoms of the treated larvae and larval mortality were assessed by observing their motility $24 \mathrm{~h}$ after exposure to their respective treatments.

\subsubsection{Photomicrography studies}

Studies of photomicrography were conducted with minor modifications based on Coelho et al. [35] methodology. Morphological alterations were checked in the 4th instar larvae of Ae. aegypti treated with LB extract and LB-ZnO $N P s$ at their median lethal concentrations $\left(L_{50}\right)$ along with the control group. The treatment groups (LB, LB-ZnO NPs) and control larvae were successively fixed at $27^{\circ} \mathrm{C}$ for $30 \mathrm{~min}$ in alcohol (ethanol) dehydration (35-70\%) and placed on glass slides. The larvae were analyzed under the Stereo zoom microscope (Leica microsystems) at $\times 20$ magnification.

\subsection{Enzymatic studies}

To study the neurotoxicity and the effect of detoxification on Ae. aegypti larvae separate studies were conducted to analyze the effect of LB extract and LB synthesized $\mathrm{ZnO}$ NPs on AChE and GST enzymes. Early 4th instar larvae were exposed for $24 \mathrm{~h}$ to LB extract and ZnO NPs at their median lethal concentrations $\left(\mathrm{LC}_{50}\right)$. It is advantageous to study the effect of a toxicant on the organism at the moment of evaluation but before mortality occurred. Accordingly, only the live larvae recovered after $24 \mathrm{~h}$ from both control and treated with LB extract and LB-ZnO NPs were used for further biochemical analysis.

\subsubsection{Preparation of whole-body homogenates for assessment of enzyme activity}

The larvae were retrieved after $24 \mathrm{~h}$ of treatment with LB aqueous extract and ZnO NPs (test larvae) alongside with untreated (control larvae) and washed with double distilled water accompanied by blotting their body surface with tissue paper to eliminate any contaminants. The collected larvae were then homogenized with a Teflon hand homogenizer in $0.5 \mathrm{ml}$ phosphate buffer [ $100 \mathrm{mM}$ phosphate buffer (pH 7.2) and 1\% Triton X-100] in Eppendorf ${ }^{\mathrm{TM}}$ tubes (submerged in ice) [36]. The homogenate was centrifuged at $10,000 \times g$ for $15 \mathrm{~min}$ at $4{ }^{\circ} \mathrm{C}$, and the supernatant was used to assess enzyme activity. Enzyme protein was estimated according to the Bradford method [37].

\subsubsection{Acetylcholinesterase (AChE) activity}

AChE activity in the whole body homogenates of larvae was spectrophotometrically measured according to a modified method of Ellman et al. [38] using acetylthiocholine iodide as a substrate [39]. $50 \mu \mathrm{l}$ aliquot of homogenate $(100 \mu \mathrm{g} / \mathrm{ml}$ crude enzyme) was successively mixed with $450 \mu$ l sodium phosphate buffer ( $100 \mathrm{mM}, \mathrm{pH} 7.5)$; $50 \mu \mathrm{l}$ of $10 \mathrm{mM}$ DTNB and $50 \mu \mathrm{l}$ of $12.5 \mathrm{mM}$ acetylcholine iodide. After $5 \mathrm{~min}$ of incubation at room temperature, the optical density of the sample was read at $400 \mathrm{~nm}$ using a spectrophotometer (Shimadzu, UV-1800) against a suitable reagent blank (without enzyme). AChE activity was expressed as ( $\mu \mathrm{mol}$ ACT released $/ \mathrm{min} / \mathrm{mg}$ protein) using published extinction coefficient $\left(\mathrm{e}=1.3 \mathrm{mM}^{-1} \mathrm{~cm}^{-1}\right)$.

\subsubsection{Glutathione S-transferase (GST) activity}

GST activity was estimated by Vontas et al. [40] method as follows. $100 \mu \mathrm{l}$ of $30 \mathrm{mM} \mathrm{CDNB}$ was added to the $100 \mu \mathrm{l}$ larval homogenate $(100 \mu \mathrm{g} / \mathrm{ml}$ crude enzyme) and the volume was adjusted to $500 \mu \mathrm{l}$ using sodium phosphate buffer (100 mM, pH 7.5). After pre-incubation of the reaction mixture at $37^{\circ} \mathrm{C}$ for $5 \mathrm{~min}, 100 \mu \mathrm{l}$ of $30 \mathrm{mM}$ of GSH was added. The change in the absorbance level was noted at $340 \mathrm{~nm}$ for $5 \mathrm{~min}$ after every $1 \mathrm{~min}$ interval in the spectrophotometer. The reaction mixture without enzyme was used as blank. GST activity was expressed as ( $\mu \mathrm{mol}$ CDNB hydrolysed $/ \mathrm{min} / \mathrm{mg}$ protein) using the published extinction coefficient $\left(\mathrm{e}=9.6 \mathrm{mM}^{-1} \mathrm{~cm}^{-1}\right)$ [41]. 


\subsection{DNA fragmentation assay}

To analyze any damage caused by LB extract and LB-ZnO NPs on mosquito DNA, fragmentation analysis was carried out as per established protocol [42]. Mosquito larvae treated with plant extract and $\mathrm{ZnO}$ NRs were washed with ethanol, distilled water to remove adhered particles. Larvae were lysed in a $250 \mu \mathrm{l}$ cell lysis buffer containing $50 \mathrm{mM}$ Tris- $\mathrm{HCl}, 0.5 \% \mathrm{SDS}, 1 \mu \mathrm{g} / \mathrm{ml}$ proteinase $\mathrm{K}(\mathrm{pH} 8.0)$, $10 \mathrm{mM}$ of ethylenediaminetetraacetic acid (EDTA) and RNase $A(0.5 \mu \mathrm{g} / \mathrm{ml})$ at $37^{\circ} \mathrm{C}$. DNA was extracted by phe$\mathrm{nol} / \mathrm{chloroform} /$ isoamyl alcohol (25:24:1) method [43]. The $260 / 280 \mathrm{~nm}$ absorbance ratio was used to assess the purity of DNA [44]. Electrophoresis of larval DNA was performed on an agarose gel (1\%) containing ethidium bromide $(1 \mu \mathrm{g} / \mathrm{ml})$ at $100 \mathrm{~V}$, and the fragments of DNA were visualized by exposing the gel to UV light and photographed on Gel documentation system (Bio-Rad Gel Doc XR system).

\subsection{Statistical data analysis}

The data acquired were analyzed using the SPSS 21.5 program for regression analysis. The values of $\mathrm{LC}_{50}$ and $\mathrm{LC}_{90}$ with $95 \%$ fiducial limits and chi-square were calculated using Probit analysis in each bioassay. The data were expressed as Mean \pm SEM. One-way variance analysis (ANOVA) followed by the post-hoc Tuckey test was performed to determine the difference in enzyme inhibition between control and treated groups. Results with $p<0.05$, were considered to be statistically significant.

\section{Results and discussion}

\subsection{Characterization}

\subsubsection{UV-Visible spectroscopy}

UV-vis spectroscopy is an easy and efficient method for the identification of nanoparticle formation, stabilization, and shape [45]. The UV-vis spectrum of LB-ZnO NPs synthesized using $L B$ aqueous extract and zinc acetate is shown in Fig. 1a. During synthesis, the color of the reaction mixture changed from yellow to pale white colored precipitate. The obtained product after calcination at $400^{\circ} \mathrm{C}$ gave white precipitate indicating the synthesis of $\mathrm{ZnO} N \mathrm{NS}$ which was further confirmed by UV-Vis spectroscopy. A characteristic absorption peak at $373.82 \mathrm{~nm}$ could be attributed, due to electron transfer from the valence band to the conductive band, related to $\mathrm{ZnO}^{\prime}$ ' intrinsic bandgap absorption (O2p-zn3d) [46]. In comparison to the average absorption at $377 \mathrm{~nm}$ of $\mathrm{ZnO} N P s$, the synthesized LB$\mathrm{ZnO} N$ Ns with a maximum wavelength at $373.82 \mathrm{~nm}$ were slightly blue-shifted which maybe because of the decrease in particle size with respect to bulk $\mathrm{ZnO}$ [47]. Mahamuni et al. [48] and Ishwarya et al. [49] reported a similar shift in the position of the absorption peak of ZnO NPs. Figure $1 \mathrm{~b}$ shows the optical energy bandgap (Eg) of LB-ZnO NPs which was estimated using the following Tauc formula [50]. (a)

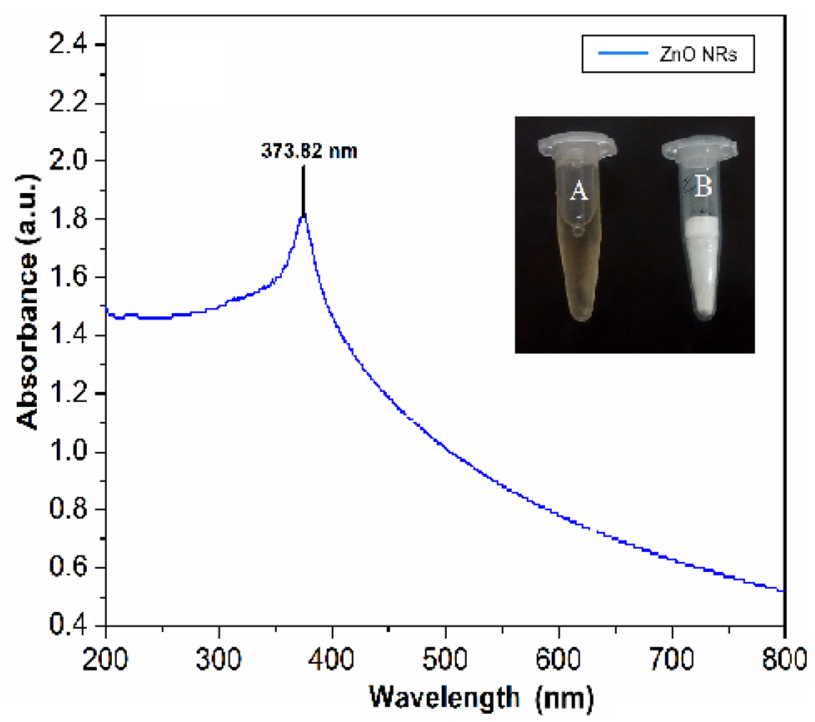

(b)

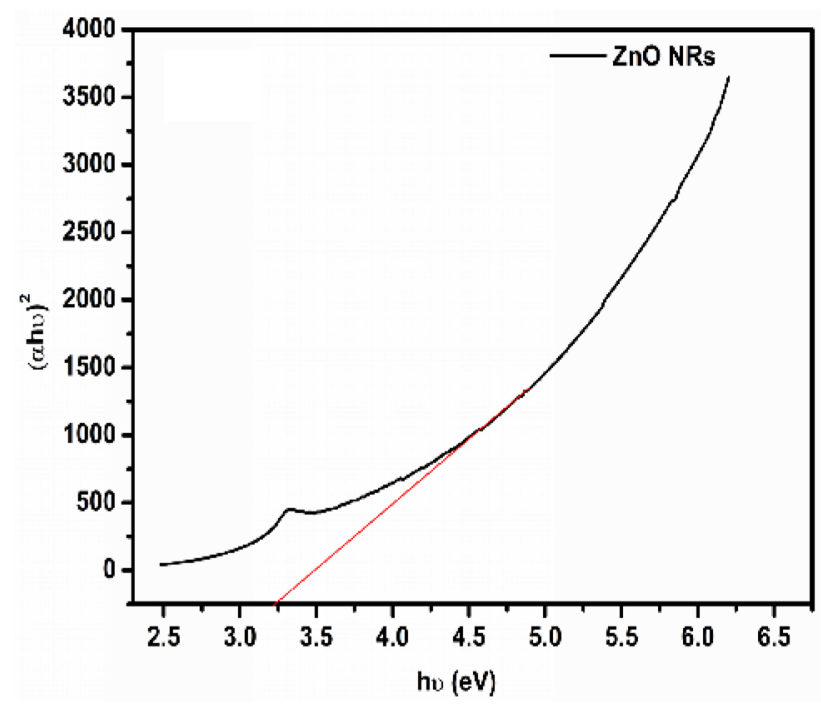

Fig. 1 a UV-visible absorption spectrum of zinc oxide nanoparticles synthesized using L. racemosa flower buds aqueous extract [Inset: (A) $L$. racemosa flower buds extract and (B) synthesized ZnO NRs]. b Optical energy band gap of synthesized ZnO nanorods 
Optical energy bandgap $(E g)=\frac{h c}{\lambda}$

where $\mathrm{h}$ and $\mathrm{c}$ refers to planks constant $\left(6.626 \times 10^{-34} \mathrm{~J} \mathrm{~s}\right)$ and velocity of light $\left(3 \times 10^{8} \mathrm{~m} / \mathrm{s}\right)$ respectively and ' $\lambda$ ' denotes optical wavelength.

The synthesized LB-ZnO NP's optical energy band gap was found to be $3.25 \mathrm{eV}$ which is in good agreement with the previous report [50]. This changes in the optical band gap of LB-ZnO NPs concerning the $\mathrm{ZnO}$ nanostructure morphology further confirms that nanostructure crystallinity, crystal growth facets, and crystal grain size lead to the effective band gap of nanostructured $\mathrm{ZnO}$ smaller than its bulk value of $3.37 \mathrm{eV}$ [51].

\subsubsection{FT-IR analysis}

FT-IR provides data on a molecule's vibrational and linear mode of motion and is, therefore, a significant method for identifying and characterizing a material. Infrared spectrum of any compound (organic or inorganic) offers a distinctive fingerprint that is easily differentiated from all other compound's absorption patterns. The FT-IR spectrum of LB aqueous extract and synthesized LB-ZnO NPs are shown in Fig. 2a, b respectively. In Fig. 2a, spectral peak at $3291 \mathrm{~cm}^{-1}$ is due to O-H stretching and $2922 \mathrm{~cm}^{-1}$ is due to $\mathrm{C}-\mathrm{H}$ stretch [52]. Absorption peak from the carbonyl group appears at $1613 \mathrm{~cm}^{-1}$, whereas the band at $1235 \mathrm{~cm}^{-1}$ observed is due to primary amine groups and $-\mathrm{C}-\mathrm{O}$ stretching mode [53]. The absorption band at $1017 \mathrm{~cm}^{-1}$ is due to $\mathrm{C}-\mathrm{N}$ stretching oscillation mode of amines that are characteristics of proteins/enzymes [54, 55]. In Fig. 2b which corresponds to the FT-IR spectrum of LB-ZnO NPs suggests that the phytoconstituents of LB aqueous extracts were either degraded or remained absorbed in smaller quantities due to calcination of NPs at higher temperature [56]. The peak observed in the present study at $900 \mathrm{~cm}^{-1}$ are due to the asymmetrical and symmetrical stretching of the zinc carboxylate. Previous reports have disscussed that the spectral signatures of carboxylate impurities gets disappear as the calcination temperature increases indicating the possibility of zinc carboxylate dissociation and conversion to $\mathrm{ZnO}$ during the calcination process [57]. Absorption at $400 \mathrm{~cm}^{-1}$ to $600 \mathrm{~cm}^{-1}$ denotes the presence of ZnO NPs as metal oxide vibrational peaks [58]. We found the similar band at $570 \mathrm{~cm}^{-1}$ which could be ascribed to $\mathrm{Zn}-\mathrm{O}$ stretching vibration of ZnO NPs [59] which can be seen in Fig. $2 \mathrm{~b}$ and is absent in LB aqueous extract (Fig. 2a). It can, therefore, be supposed that the ZnO NPs is synthesized and stabilized by carboxyl, methyl and hydroxyl groups in the phytoconstituents of LB extract but after calcination, these organic molecules were degraded.

\subsubsection{XRD analysis}

$\mathrm{XRD}$ is a robust, non-destructive analytical tool used to classify and quantitatively evaluate various crystalline compounds. The XRD spectra of ZnO NPs synthesized with LB extract is illustrated in Fig. 3. X-ray diffraction peaks recorded at $31.75^{\circ}, 34.52^{\circ}, 36.23^{\circ}, 47.53^{\circ}, 56.58^{\circ}, 62.84^{\circ}$, $66.24^{\circ}, 67.92^{\circ}, 69.04^{\circ}, 72.65^{\circ}$, and $76.92^{\circ}$ are attributed
Fig. 2 FTIR spectrum of $(a) L$. racemosa flower buds extract. (b) Bio synthesized L. racemosa flower buds mediated ZnO NRs

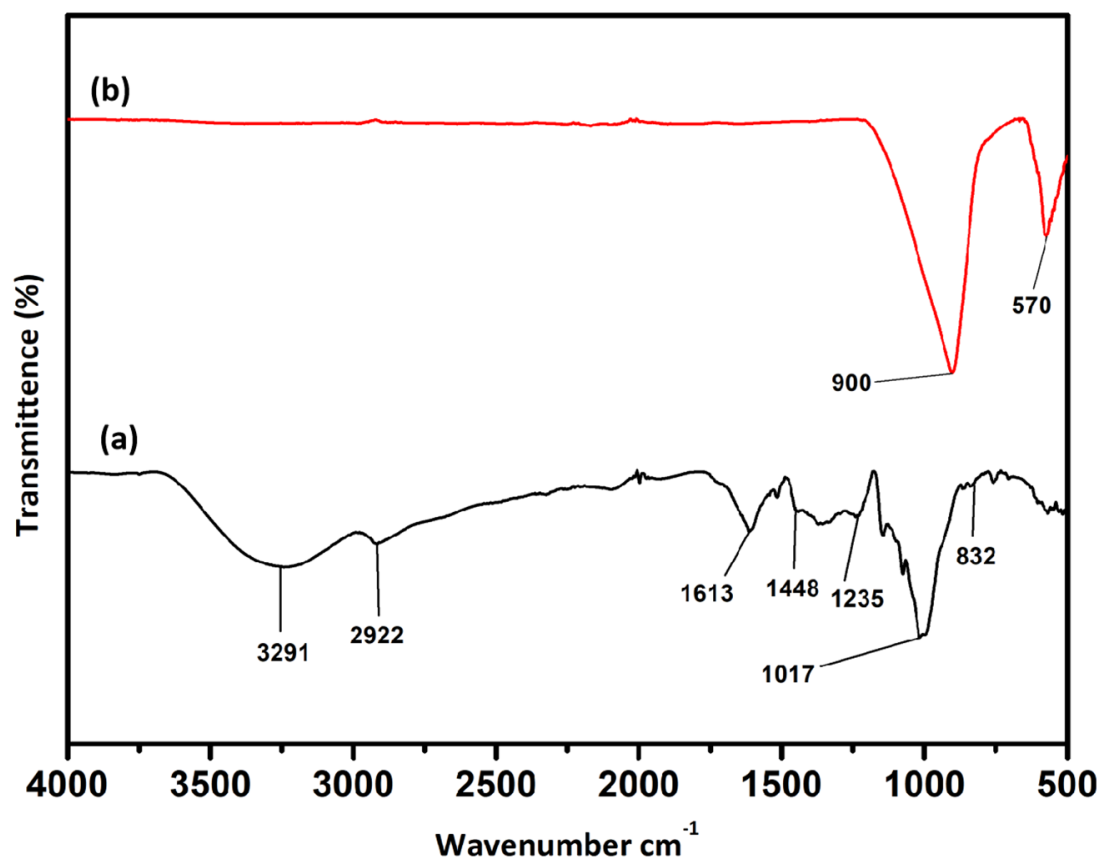


to crystal planes of (100), (002), (101), (102), (110), (103), (200), (112), (201), (004) and (202) of synthesized LB-ZnO NPs, which corresponds to hexagonal wurtzite structural characteristics (JCPDS card number 36-1451, International Diffraction Data Center ver. 2002). Besides, no additional peaks in diffraction could be found in the XRD spectrum of LB-ZnO NPs suggesting complete decomposition of LB extract and zinc acetate precursor, without any other crystal impurities. Our findings are comparable with Narendhran and Shivaraj [60], who have developed ZnO NPs using the Lantana aculeata leaf extract and to Vanathi et al. [61], where ZnO NPs were synthesized using Eichorrnia crassipes leaf extract. The average crystalline size of synthesized ZnO NPs was calculated to be $30.321 \mathrm{~nm}$ using the Debey-Scherrer equation as follows [62].

$D=\frac{k \lambda}{\beta \cos \theta}$

where $D$ is the crystalline size, $K$ is the shape factor i.e. 0.94, $\lambda$ is the X-Ray wavelength (1.5406 $\AA$ ), $\beta$ is Full Width at half maximum (FWHM) in radians and $\theta$ is the Bragg angle.

\subsubsection{SEM and EDS analysis}

The surface morphology and topography of the synthesized particles can be analyzed using SEM. In the present study, the SEM micrograph images (Fig. 4a, b) revealed the formation of zinc oxide nanorods with an average size of 250-300 nm. The resulting morphology of ZnO NRs was quite similar to earlier reported literature [63]. Rods with small morphology is usually preferred for the biomedical field while $\mathrm{ZnO}$ rods have better optical characteristics that can lead to significant pharmacological properties [64]. EDX spectrum revealed that there was a strong signal from the $\mathrm{Zn}$ atoms along with a low signal from the $\mathrm{O}$ atoms represented in Fig. 4c confirming ZnO NRs formation. Also, we found the presence of two small elemental peaks at around 9.5 and $8.5 \mathrm{keV}$ ascribed to elemental zinc. Previous studies have reported major peaks at 1 to $10 \mathrm{keV}$ in ZnO NPs synthesized using Trifolium pratense flower extract [65]. From the figure, we can observe the peaks of zinc and oxygen along with carbon, which may have come because of phytoconstituents from LB aqueous extract which acted as a capping agent to NPs. The figure also displays the major element as zinc which comprises more than $80 \%$ of total constituent along with oxygen, which further confirms the formation of pure ZnO NRs from LB extract.

\subsubsection{TEM analysis}

The TEM analysis of the synthesized LB-ZnO NPs is shown in Fig. 5. TEM micrographs of the produced nanoparticles at different magnifications are shown in Fig. $5 \mathrm{a}-\mathrm{c}$ which clearly shows mixed morphology of ZnO NPs. Synthesized NPs were mostly rod-like structures with the average size in the range of $250-300 \mathrm{~nm}$ in length and $45-50 \mathrm{~nm}$ in diameter. Comparable results were found using Myristica fragrans leaves extract synthesized $\mathrm{ZnO}$ nanorods ( $\mathrm{ZnO}$ NRs) with a range of 50-100 nm [66]. Another report demonstrated the synthesis of $\mathrm{ZnO}$ NRs using Ricinus
Fig. 3 X-ray diffraction analysis of zinc oxide nanorods biosynthesized using the $L$. racemosa flower buds extract

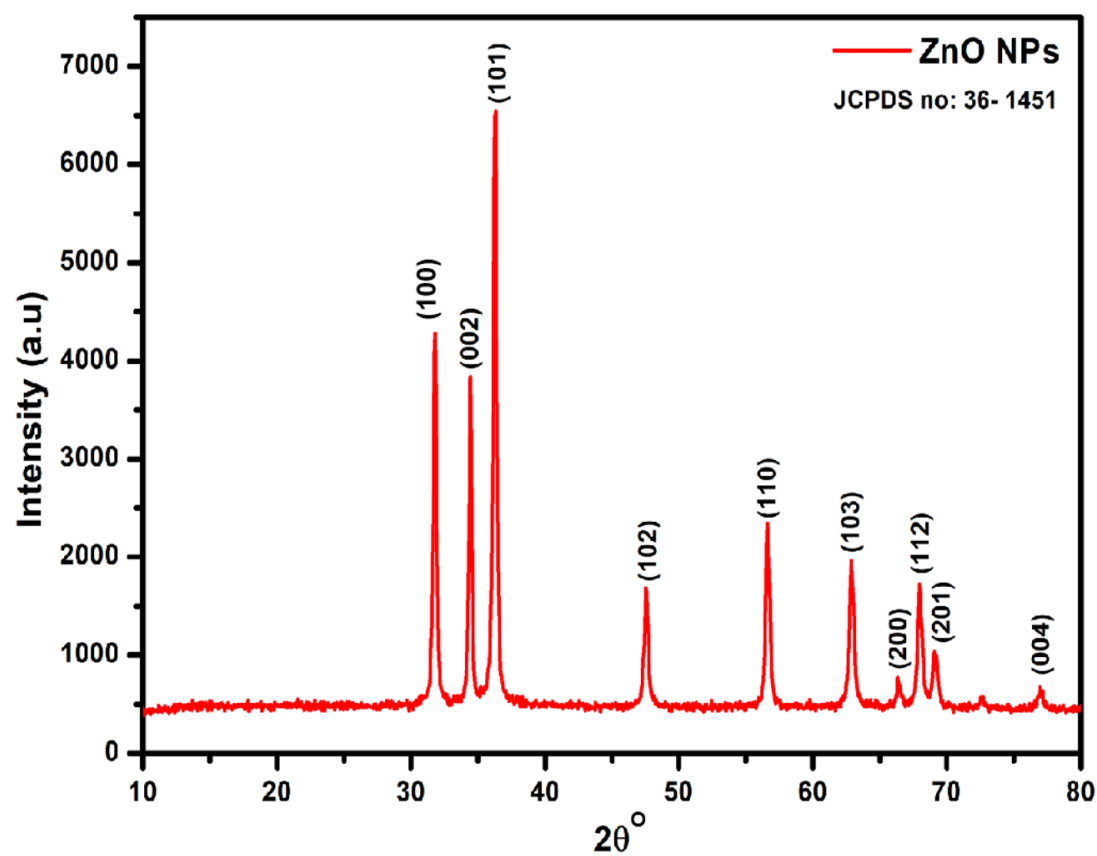

SN Applied Sciences A SPRINGER NATURE journa 


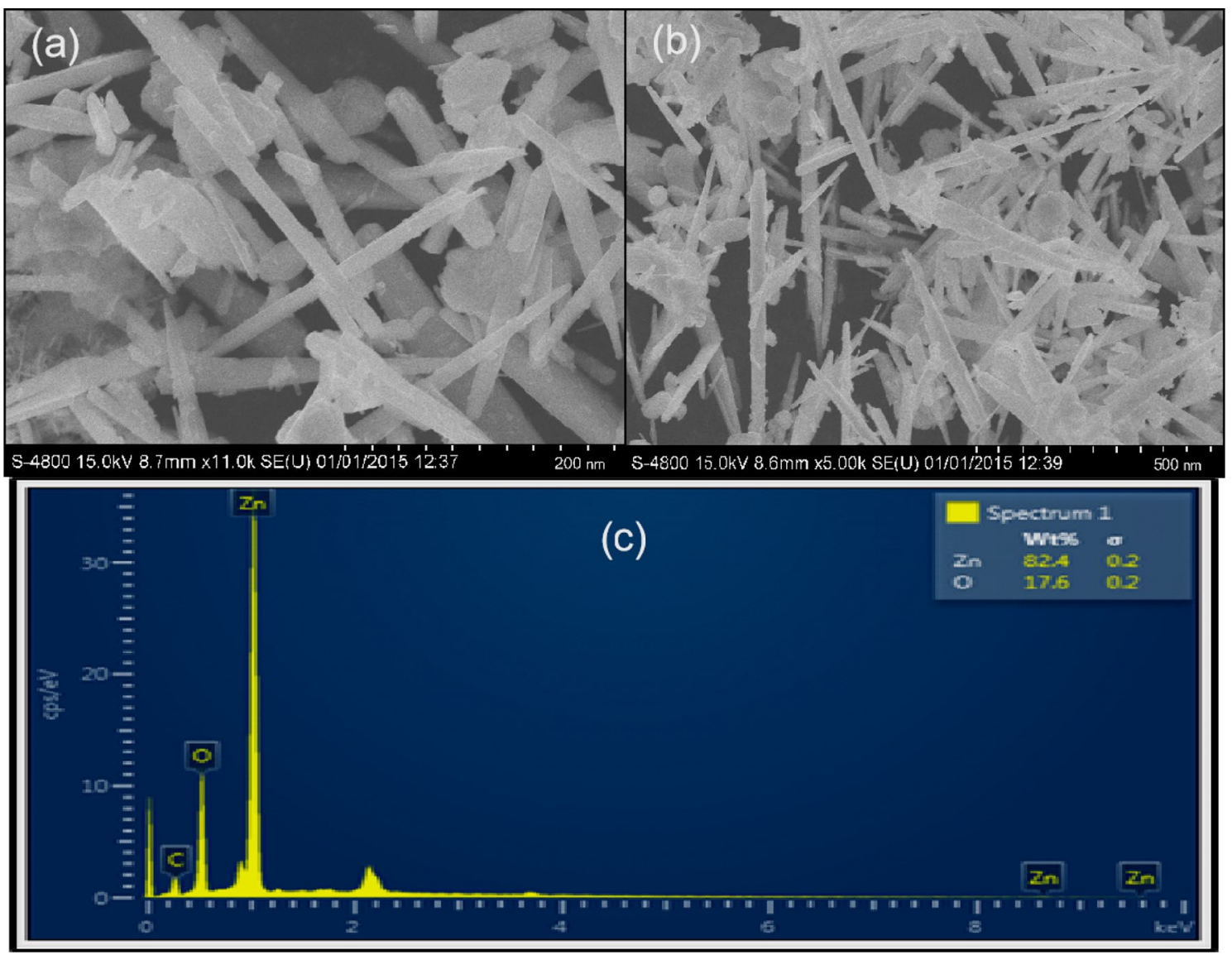

Fig. 4 a, b SEM image of ZnO nanorods synthesized from L. racemosa flower buds exact. c EDS analysis of ZnO nanorods biosynthesized using $L$. racemosa flower buds extract

communis $\mathrm{L}$. leaf extract which had a diameter of $52.84 \mathrm{~nm}$ and length of $700 \mathrm{~nm}$ [67]. Figure 5e shows the selected area diffraction pattern (SAED) of $L$. racemos a flower buds fabricated $\mathrm{ZnO}$ NRs, corresponding to the hexagonal wurtzite structure of $\mathrm{ZnO}$ which correlates well with the XRD results.

\subsubsection{Surface charge and stability by Zeta potential}

The surface charge and stability of the synthesized LB-ZnO NRs was analysed by Zeta potential (ZP). Surface charge plays an important role in confirming the stability of NPs in a liquid medium. The zeta potential value for LB-ZnO NRs was around $-23.5 \mathrm{mV}$ (Fig. 6) indicating a negative surface charge on synthesized NPs. Similar results were obtained by ZnO NRs synthesized using Santalum album leaf extract with zeta potential value of $-13 \mathrm{mV}$ [68]. It should be noted that the particles with zeta potential values more positive than $+30 \mathrm{mV}$ or more negative than $-30 \mathrm{mV}$ are considered to be stable [69]. In contrast, the colloids are least stable at the isoelectric point, where the zeta potential is zero. The high negative value on synthesized LB-ZnO
NRs confirms the repulsion among the particles and suggesting the synthesized NRs are stable.

\subsection{Mosquito larvicidal activity}

Different concentrations of LB extract and synthesized LB$\mathrm{ZnO}$ NRs were tested on the early 4th instar larvae of $A e$. aegypti for $24 \mathrm{~h}$ to evaluate their efficacy. Results indicate as the concentration of plant extracts and $\mathrm{ZnO}$ NRs increased the mortality of mosquito larvae increased. The LB aqueous extract was less toxic than synthesized LB-ZnO NRs against Ae. aegypti. 100\% mortality was recorded by $\mathrm{LB}-\mathrm{ZnO} N$ Rs at $50 \mu \mathrm{g} / \mathrm{ml}$ with $\mathrm{LC}_{50}$ and $\mathrm{LC}_{90}$ values of 24.74 and $42.09 \mu \mathrm{g} / \mathrm{ml}$ respectively. While LB extract showed $100 \%$ mortality at $2500 \mu \mathrm{g} / \mathrm{ml}$ with $\mathrm{LC}_{50}$ and $\mathrm{LC}_{90}$ values of 1333.75 and $2216.48 \mu \mathrm{g} / \mathrm{ml}$ respectively (Table 1 ). Control did not show any toxicity to mosquito larvae and $\chi^{2}$ value shows a significant difference at $p<0.05$ level. Results indicate the larvicidal potential of LB-ZnO NRs being 50 folds more potent than LB extract. There are no reports on the larvicidal activity of $\mathrm{ZnO}$ NRs synthesized from $L$. racemosa plant but few mangroves have been screened

\section{SN Applied Sciences}




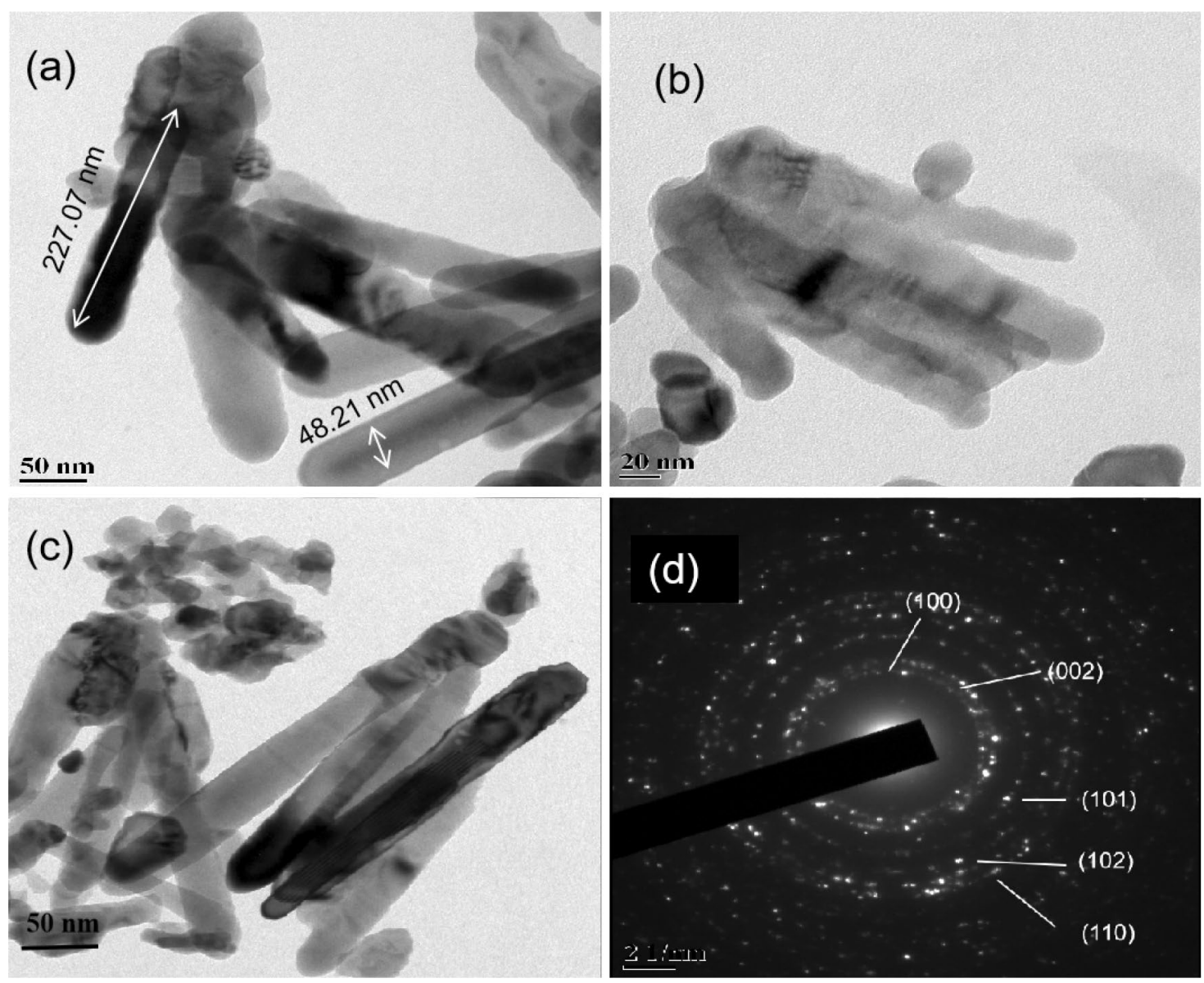

Fig. 5 a-c represents TEM images of bio-synthesized ZnO NRs using L. racemosa aqueous extract, $\mathbf{d}$ SAED pattern of synthesized ZnO NRs

Fig. 6 Zeta potential of biosynthesized ZnO NRs in deionized water

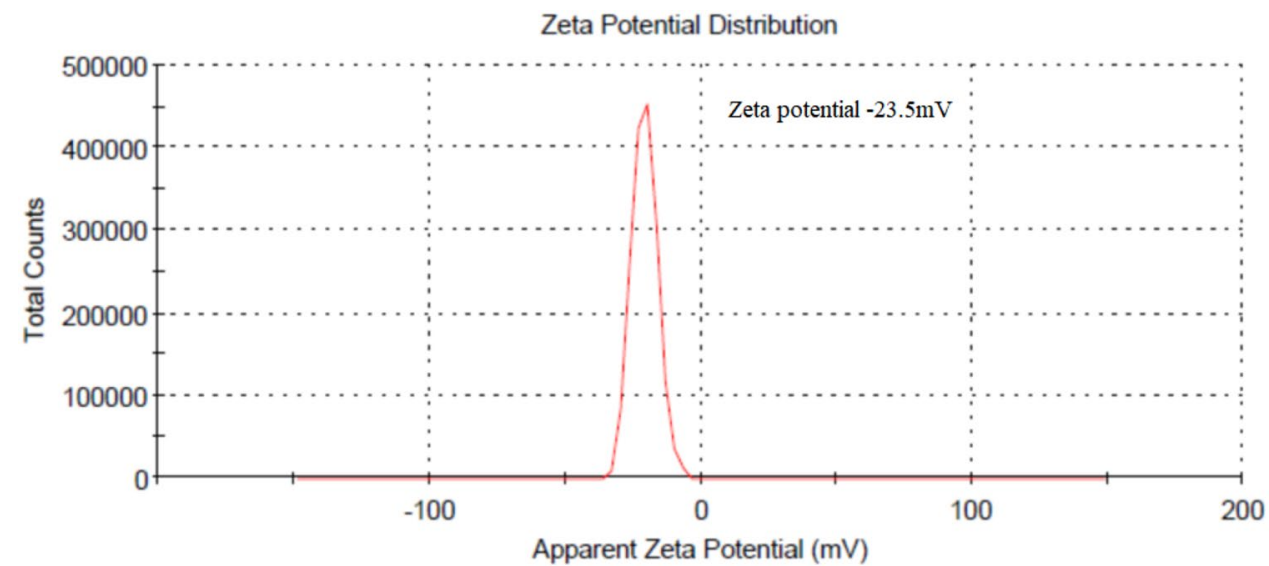

The mortality effect of LB-ZnO NRs on mosquito larvae can be attributed to the internal toxic effects of tiny particles inside the cuticle and the accumulation of LB-ZnO NRs in the alimentary canal. Also, small particles have been reported to target individual cells and interfere with moulting and other physiological processes which hinders the development of mosquito larvae [71]. Similar results for their larvicidal activity. Jisha and Shreeja [17] showed potential larvicidal activity against $A$ e. aegypti larvae by $L$. racemosa leaf acetone extract with an $\mathrm{LC}_{50}$ value of $8 \mathrm{mg} / \mathrm{L}$. Similar results were also recorded by Ali et al. [70] in $E$. agallocha leaf ethanol extract on Ae. aegypti larvae with $\mathrm{LC}_{50}$ value of $67.1 \mathrm{mg} / \mathrm{ml}$. 
Table 1 Larvicidal toxicity of L. racemosa flower buds extract and synthesized $\mathrm{ZnO}$ nanorods against the dengue vector Aedes aegypti

\begin{tabular}{|c|c|c|c|c|c|c|c|}
\hline Treatment & $\begin{array}{l}\text { Concentra- } \\
\text { tion }(\mu \mathrm{g} / \\
\mathrm{ml})\end{array}$ & $\begin{array}{l}24 \text { h mortality } \\
(\%) \pm \text { SEM }\end{array}$ & $\mathrm{LC}_{50}(\mu \mathrm{g} / \mathrm{ml})$ & LCL-UCL & $\mathrm{LC}_{90}(\mu \mathrm{g} / \mathrm{ml})$ & LCL-UCL & $\chi^{2 *}$ (d.f.) \\
\hline \multirow{5}{*}{$\begin{array}{l}\text { L. racemosa flower } \\
\text { buds aqueous } \\
\text { extract }\end{array}$} & 500 & $17.5 \pm 1.44$ & \multirow[t]{5}{*}{1333.75} & \multirow[t]{5}{*}{ 1104.59-1569.60 } & \multirow[t]{5}{*}{2216.48} & \multirow[t]{5}{*}{ 1917.77-2741.08 } & \multirow[t]{5}{*}{$12.57(5)(p=0.014)$} \\
\hline & 1000 & $33.34 \pm 1.77$ & & & & & \\
\hline & 1500 & $54.16 \pm 2.37$ & & & & & \\
\hline & 2000 & $78.75 \pm 2.31$ & & & & & \\
\hline & 2500 & $99.16 \pm 0.56$ & & & & & \\
\hline \multirow{5}{*}{$\begin{array}{l}\text { Synthesized ZnO } \\
\text { NRs }\end{array}$} & 10 & $15.83 \pm 1.82$ & \multirow[t]{5}{*}{24.74} & \multirow[t]{5}{*}{$20.22-29.23$} & \multirow[t]{5}{*}{42.09} & \multirow[t]{5}{*}{$36.41-51.85$} & \multirow[t]{5}{*}{$12.17(5)(p=0.016)$} \\
\hline & 20 & $43.33 \pm 2.77$ & & & & & \\
\hline & 30 & $62.91 \pm 3.91$ & & & & & \\
\hline & 40 & $80.05 \pm 7.68$ & & & & & \\
\hline & 50 & $100.00 \pm 0.00$ & & & & & \\
\hline
\end{tabular}

Control group did not showed any mortality

$L C_{50}$ lethal concentration $(\mu \mathrm{g} / \mathrm{ml})$ that kills $50 \%$ of the exposed organisms, $L C_{90}$ lethal concentration $(\mu \mathrm{g} / \mathrm{ml})$ that kills $90 \%$ of the exposed organisms, $\chi^{2}$ Chi square, d.f. degrees of freedom

*Significance at $(p \leq 0.05)$

were obtained by ZnO NRs synthesized using Myristica fragrans aqueous leaf extract and Ulva lactuca-fabricated ZnO NPs which was highly effective against Ae. aegypti 4th instar larvae $[49,66]$.

Mosquito larvicidal toxicity was further studied through morphological changes by exposing LB extract and LBZnO NRs at their highest concentration and visualizing affected larvae under the Stereo Zoom microscope (Fig. 7). On treatment with both LB extract and LB-ZnO NRs, Ae. aegypti larval body shrank and darkened which gave burnt like appearance. Besides, larvae treated with LB-ZnO NRs showed an accumulation of NRs in the alimentary canal and the respiratory region i.e., siphon. These morphological changes seem to be responsible for the larvicidal toxicity by LB extract and LB-ZnO NRs. Similar morphological damages were reported by Abinaya et al. [72] when Ae. aegypti larvae were treated with bacterial exopolysaccharide (EPS)-coated $\mathrm{ZnO}$ nanoparticles.

Overall the results suggest that mortality in larvae might be due to the accumulation of LB-ZnO NRs in the entire alimentary canal and in the siphon region.

\subsection{Enzyme activity}

\subsubsection{Acetylcholinesterase activity}

AChE is an enzyme involved in the hydrolysis of acetylcholine and its activity is inhibited by the tested compounds at nerve synapses and neuromuscular junctions. Many insecticide classes such as organophosphates and carbamates are responsible for inhibition of AChE irreversibly and causes insect mortality [73]. AChE enzyme was used as a surrogate biomarker to assess the neurotoxicity in vitro
[74]. Given this, we carried out a study involving the effect of LB extract and LB-ZnO NRs on AChE activity of Ae. aegypti 4th instar larvae. The exposure of the larvae to LB extract and LB-ZnO NRs for $24 \mathrm{~h}$ significantly decreased the AChE activity to $2.42 \mu \mathrm{M} \mathrm{ACT} / \mathrm{mg} / \mathrm{min}$ and $1.41 \mu \mathrm{M}$ $\mathrm{ACT} / \mathrm{mg} / \mathrm{min}$ respectively compared to the control value of $3.58 \mu \mathrm{M} \mathrm{ACT} / \mathrm{mg} / \mathrm{min}$ of homogenate (Fig. 8). This corresponds to $32 \%$ and $60.6 \%$ inhibition of $A C h E$ activity in larvae treated with LB extract and LB-ZnO NRs. Previous reports of mangroves plants viz. Rhizophora apiculata, Rhizophora annamalayana, Rhizophora mucronata, Avicennia marina and Bruguiera cylindrica showed $50 \%$ inhibition of AChE activity in mosquito larvae [75]. Extracts of Sapindus emarginatus showed comparable results to our study by altering the rates of AChE significantly in dengue larvae [76]. For biomonitoring studies and metal toxicity experiments on cholinesterases (ChEs), assessing the effect of metals on the activity of AChE has been a major challenge. Nevertheless, little work has been done to examine the interactions between AChE and metallic nanoparticles $[77,78]$. There are no reports on the AChE inhibition in Ae. aegypti larvae by $\mathrm{ZnO}$ NRs using mangrove plant extracts. However silver nanoparticles synthesized using Cassia fistula-fruit pulp extract demonstrated lowered AChE activity of $62 \%$ in Aedes albopictus larvae [79]. Similarly, inhibition in AChE activity was observed by a-chitin nanoparticles, silver nanoparticles synthesized using shells of Penaeus monodon Fabricius and their nanocomposite when treated against Ae. aegypti larvae [80]. According to previous studies, it was found that toxic compounds affect the digestive system, the respiratory system and the nervous system in the larvae [81]. AChE enzyme inhibition causes the muscles to remain contracted leading to paralysis and finally 

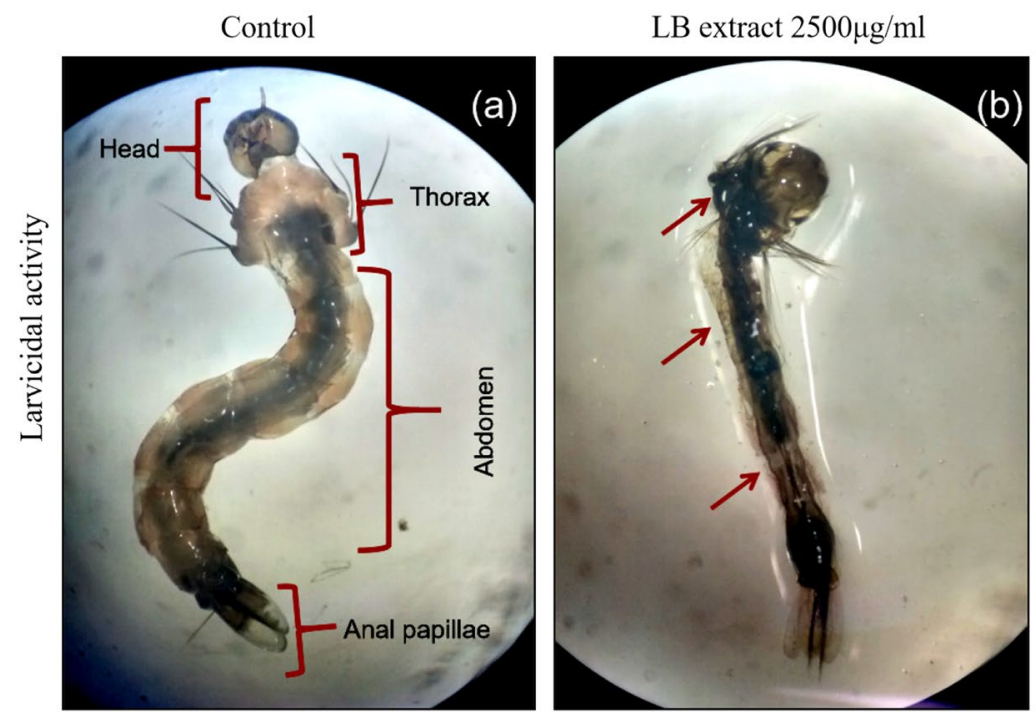

LB-ZnO NRs $50 \mu \mathrm{g} / \mathrm{ml}$

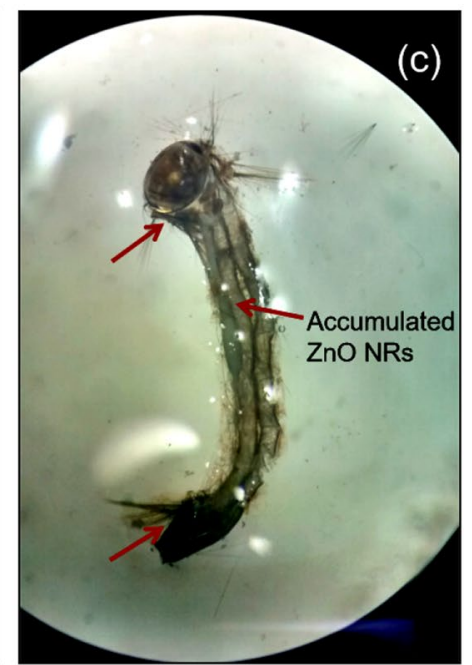

Fig. 7 Morphological changes in Ae. aegypti larvae after 24 h. a Control larvae after $24 \mathrm{~h}$, b when exposed to L. racemosa flower buds extract $c$ L. racemosa flower buds extract synthesized $\mathrm{ZnO}$
NRs. Arrow in red color $(\rightarrow)$ indicates the damages to head, abdominal region, thorax region and siphon

\subsubsection{Glutathione S-transferase activity}

GST normally plays an important role in detoxification of exogenous compounds. Compounds such as insecticides enter target insect tissues and organs and affect the activity of different detoxifying enzymes. Some compounds may inhibit the activity of GSTs, while others may enhance the activity of GSTs [83]. In this study, there was a slight increase in GST activity by LB extract $(0.416 \mu \mathrm{M}$ CDNB conjugated $/ \mathrm{min} / \mathrm{mg}$ protein) while significant decrease in GST activity was witnessed in larvae treated with LBZnO NRs ( $0.276 \mu \mathrm{M}$ CDNB conjugated $/ \mathrm{min} / \mathrm{mg}$ protein) as compared to control ( $0.37 \mu \mathrm{M} \mathrm{CDNB}$ conjugated/min/ mg protein) (Fig. 9). Thus $11 \%$ increment in GST activity in Ae. aegypti larvae when treated with LB aqueous extract signifies the larvae were trying to detoxify plant metabolites. In contrast, $25 \%$ reduction in GST activity by LB-ZnO NRs indicated that the ZnO NRs might be involved in a redox reaction and causes oxidative stress damage in the larval tissues [84-86]. A similar decrease in GST activity was shown by Pongamia pinnata leaf extract coated $\mathrm{ZnO}$ nanoparticles in Callosobruchus maculatus [28]. Thus inhibition or stimulation of these enzymes by insecticides can lead to metabolic inequalities, growth retardation and induction of mortality in mosquito larvae [87].

\subsection{DNA fragmentation assay}

The purity of DNA was recorded and the A260/A280 ratio was found to be $1.8-2.0 \pm 0.05$. LB aqueous extract displayed slight but significant damage to the $A e$. of LB-ZnO NRs. 


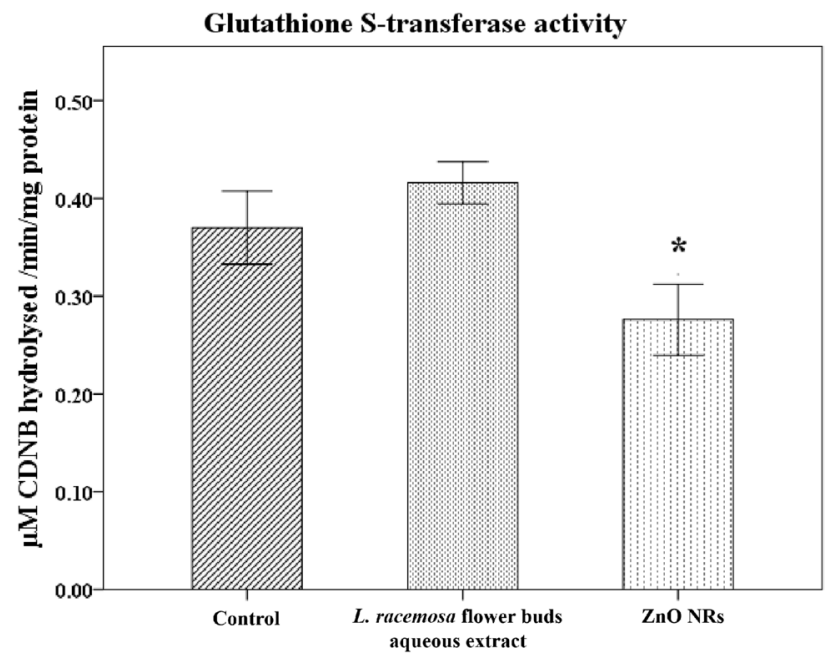

Fig. 9 Activity of Glutathione S- transferase of Ae. aegypti larvae treated at $\mathrm{LC}_{50}$ concentration of $L$. racemosa flower buds aqueous extract and $L$. racemosa flower synthesized $Z n O$ NRs. Results are presented as mean \pm SEM $(n=3)$. ${ }^{*} p<0.05$ (ANNOVA, Tukey's HSD test) denote significant difference compared to the control

aegypti larval DNA as compared to LB-ZnO NRs and control-treated larval DNA (Fig. 10). This indicates that synthesized LB-ZnO NRs do not demonstrate any nicking activity in mosquito DNA confirming the mortality of larvae is based solely on cytotoxicity and can be used as a safe alternative to commercial insecticides in the field.

\section{Conclusion}

This study reports for the first time green synthesis of zinc oxide nanorods using $L$. racemosa flower buds. The characterization results recorded from UV-Vis spectrophotometry, TEM, SEM, XRD, FTIR and EDX analyses support the effective biosynthesis of $L$. racemosa flower buds extract fabricated ZnO NRs. The synthesized LB-ZnO NRs are crystalline with an average length of $250-300 \mathrm{~nm}$ and 40-50 nm in diameter. Present research highlighted that the $\mathrm{ZnO}$ NRs are easy to produce, and can be employed at low dosages to strongly reduce populations of the dengue vector, Ae. aegypti with $\mathrm{LC}_{50}$ at $24.74 \mu \mathrm{g} / \mathrm{ml}$. Besides, LB-ZnO NRs also affected the activity of enzymes in $A e$. aegypti larvae, which demonstrated decreased AChE and GST activity, responsible for signal transduction and resistivity of xenobiotics with no genetic impairment. The study concludes that LB-ZnO NRs can be used as an efficient nanobiopesticides for controlling dengue vector $A e$. aegypti larvae in the future.

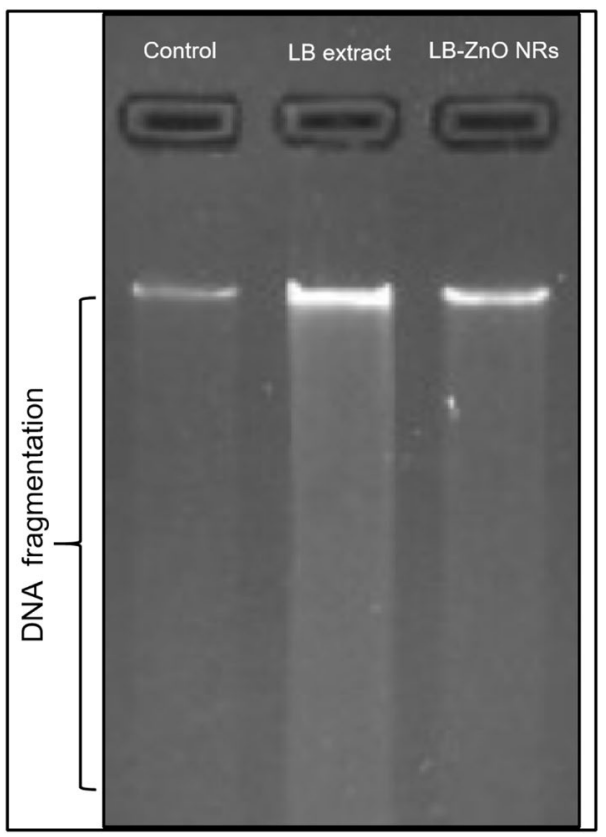

Fig. 10 DNA fragmentation assay of Ae. aegypti larvae treated with $L$. racemosa flower buds aqueous extract $(\mathrm{LB})$ and $L$. racemosa flower synthesized ZnO NRs (LB-ZnO NRs) as compared to control

Acknowledgements Authors are thankful to the Department of Life Sciences, Department of Chemistry, National Centre for Nanoscience and Nanotechnology, University of Mumbai; IIT Bombay (SAIF) for accessing Instrument Facility. Department of Zoonosis, Haffkine Institute for Training Research \& Testing Mumbai, Maharashtra for identification of Mosquito species.

\section{Compliance with ethical standards}

Conflict of interest Authors declare no conflict of interest.

\section{References}

1. Benelli G, Mehlhorn H (2016) Declining malaria, rising of dengue and Zika virus: insights for mosquito vector control. Parasitol Res 115(5):1747-1754. https://doi.org/10.1007/s00436-016-4971-z

2. World Health Organization (2012) Handbook for integrated vector management. World Health Organization, Geneva

3. Veerakumar K, Govindarajan M, Rajeswary M, Muthukumaran U (2014) Mosquito larvicidal properties of silver nanoparticles synthesized using Heliotropium indicum (Boraginaceae) against Aedes aegypti, Anopheles stephensi and Culex quinquefasciatus (Diptera: Culicidae). Parasitol Res 113(6):2363-2373. https://doi. org/10.1007/s00436-014-3895-8

4. Benelli G, Romano D (2017) Mosquito vectors of Zika virus. Entomol Gener. https://doi.org/10.1127/entomologia/2017/0496

5. Harrington LC, Scott TW, Lerdthusnee K, Coleman RC, Costero A, Clark GG, Jones JJ, Kitthawee S, Kittayapong P, Sithiprasasna R, Edman JD (2005) Dispersal of the dengue vector Aedes aegypti within and between rural communities. Am J Trop Med Hyg 72(2):209-220. https://doi.org/10.4269/ajtmh.2005.72.209 
6. Murugan K, Hwang JS, Kovendan K, Kumar KP, Vasugi C, Kumar AN (2011) Use of plant products and copepods for control of the dengue vector, Aedes aegypti. Hydrobiologia 666:331-338. https://doi.org/10.1007/s10750-011-0629-0

7. De Castro BM, De Jaeger X, Martins-Silva C, Lima RD, Amaral E, Menezes C, Lima P, Neves CM, Pires RG, Gould TW, Welch I (2009) The vesicular acetylcholine transporter is required for neuromuscular development and function. Mol Cell Biol 29(19):52385250. https://doi.org/10.1128/MCB.00245-09

8. Melo-Santos MA, Varjal-Melo JJ, Araújo AP, Gomes TC, Paiva MH, Regis LN, Furtado AF, Magalhaes T, Macoris ML, Andrighetti MT, Ayres CF (2010) Resistance to the organophosphate temephos: mechanisms, evolution and reversion in an Aedes aegypti laboratory strain from Brazil. Acta Trop 113(2):180-189. https://doi. org/10.1016/j.actatropica.2009.10.015

9. Benelli G (2015) Research in mosquito control: current challenges for a brighter future. Parasitol Res 114(8):2801-2805. https://doi.org/10.1007/s00436-015-4586-9

10. Fillinger U, Lindsay SW (2011) Larval source management for malaria control in Africa: myths and reality. Malaria J 10(353):1 10. https://doi.org/10.1186/1475-2875-10-353

11. Azizullah A, Rehman ZU, Ali I, Murad W, Muhammad N, Ullah W, Häder DP (2014) Chlorophyll derivatives can be an efficient weapon in the fight against dengue. Parasitol Res 113(12):43214326. https://doi.org/10.1007/s00436-014-4175-3

12. De Lacerda LD, Jose DV, De Rezende CE, Maria Cristina F, Wasserman JC, Martins JC (1986) Leaf chemical characteristics affecting herbivory in a New World mangrove forest. Biotropica 18:350-355

13. Anjaneyulu M, Chopra K (2003) Quercetin, a bioflavonoid, attenuates thermal hyperalgesia in a mouse model of diabetic neuropathic pain. Prog Neuropsychopharmacol Biol Psychiatry 27(6):1001-1005. https://doi.org/10.1016/S0278-5846(03)00160 $-\mathrm{X}$

14. DeSouza L, Wahidullah S (2010) Antibacterial phenolics from the mangrove Lumnitzera racemosa. Indian J Mar Sci 39(2):294-298

15. Lin TC, Hsu FL, Cheng JT (1993) Antihypertensive activity of corilagin and chebulinic acid, tannins from Lumnitzera, racemosa. J Nat Prod 56(4):629-632. https://doi.org/10.1021/np500 $94 \mathrm{a} 030$

16. Ravikumar S, Gnanadesigan M (2011) Hepatoprotective and antioxidant activity of a mangrove plant Lumnitzera racemosa. Asian Pac J Trop Biomed 1(5):348-352. https://doi.org/10.1016/ S2221-1691(11)60078-6

17. Jisha S, Sreeja J (2018) Preliminary study on the mosquito larvicidal efficacy of mangrove leaf extracts. Indian J Sci Res 20(1):68-70

18. Lardeux $F$, Rivière $F$, Sechan $Y$, Loncke $S$ (2002) Control of the Aedes vectors of the dengue viruses and Wuchereria bancrofti: the French Polynesian experience. Ann Trop Med Parasitol 96(2):105-116. https://doi.org/10.1179/000349802125002455

19. Banumathi $B$, Vaseeharan $B$, Ishwarya $R$, Govindarajan $M$, Alharbi NS, Kadaikunnan S et al (2017) Toxicity of herbal extracts used in ethno-veterinary medicine and green-encapsulated $\mathrm{ZnO}$ nanoparticles against Aedes aegypti and microbial pathogens. Parasitol Res 116(6):1637-1651. https://doi.org/10.1007/s0043 6-017-5438-6

20. Murugan K, Benelli G, Panneerselvam C, Subramaniam J, Jeyalalitha T, Dinesh D et al (2015) Cymbopogon citratus-synthesized gold nanoparticles boost the predation efficiency of copepod Mesocyclops aspericornis against malaria and dengue mosquitoes. Exp Parasitol 153:129-138. https://doi.org/10.1016/j.exppa ra.2015.03.017

21. Ishwarya R, Vaseeharan B, Anuradha R, Rekha R, Govindarajan M, Alharbi NS et al (2017) Eco-friendly fabrication of Ag nanostructures using the seed extract of Pedalium murex, an ancient
Indian medicinal plant: Histopathological effects on the Zika virus vector Aedes aegypti and inhibition of biofilm-forming pathogenic bacteria. J Photochem Photobiol B 174:133-143. https://doi.org/10.1016/j.jphotobiol.2017.07.026

22. Sirelkhatim A, Mahmud S, Seeni A, Kaus NH, Ann LC, Bakhori SK, Hasan H, Mohamad D (2015) Review on zinc oxide nanoparticles: antibacterial activity and toxicity mechanism. Nano-Micro Lett 7(3):219-242. https://doi.org/10.1007/s40820-015-0040-x

23. Fortunato EM, Barquinha PM, Pimentel AC, Gonçalves AM, Marques AJ, Pereira LM, Martins RF (2005) Fully transparent ZnO thin-film transistor produced at room temperature. Adv Mater 17(5):590-594. https://doi.org/10.1002/adma.200400368

24. Loan TT, Long NN (2009) Photoluminescence properties of Co-doped $\mathrm{ZnO}$ nanorods synthesized by hydrothermal method. J Phys D 42(6):065412. https://doi.org/10.1088/0022$3727 / 42 / 6 / 065412$

25. Nie L, Gao L, Feng P, Zhang J, Fu X, Liu Y, Yan X, Wang T (2006) Three-dimensional functionalized tetrapod-like $\mathrm{ZnO}$ nanostructures for plasmid DNA delivery. Small 2(5):621-625. https://doi. org/10.1002/smll.200500193

26. Yoon SH, Kim DJ (2006) Fabrication and characterization of $\mathrm{ZnO}$ films for biological sensor application of FPW device. In: Proceedings of the 2006 15th IEEE international symposium on the applications of ferroelectrics Jul 30, 322-325. IEEE.

27. Xiong HM (2013) ZnO nanoparticles applied to bioimaging and drug delivery. Adv Mater 25(37):5329-5335. https://doi. org/10.1002/adma.201301732

28. Malaikozhundan B, Vaseeharan B, Vijayakumar S, Pandiselvi K, Kalanjiam MAR, Murugan K, Benelli G (2017) Biological therapeutics of Pongamia pinnata coated zinc oxide nanoparticles against clinically important pathogenic bacteria, fungi and MCF-7 breast cancer cells. Microb Pathog 104:268-277. https ://doi.org/10.1016/j.micpath.2017.01.029

29. Applerot G, Lipovsky A, Dror R, Perkas N, Nitzan Y, Lubart R, Gedanken A (2009) Enhanced antibacterial activity of nanocrystalline $\mathrm{ZnO}$ due to increased ROS-mediated cell injury. Adv Func Mater 19(6):842-852. https://doi.org/10.1002/adfm.200801081

30. Sharma D, Rajput J, Kaith BS, Kaur M, Sharma S (2010) Synthesis of $\mathrm{ZnO}$ nanoparticles and study of their antibacterial and antifungal properties. Thin Solid Films 519(3):1224-1229. https:// doi.org/10.1016/j.tsf.2010.08.073

31. Kirthi AV, Rahuman AA, Rajakumar G, Marimuthu S, Santhoshkumar T, Jayaseelan C, Velayutham K (2011) Acaricidal, pediculocidal and larvicidal activity of synthesized $\mathrm{ZnO}$ nanoparticles using wet chemical route against blood feeding parasites. Parasitol Res 109(2):461-472. https://doi.org/10.1007/s0043 6-011-2277-8

32. Kumar S, Warikoo R, Wahab N (2010) Larvicidal potential of ethanolic extracts of dried fruits of three species of peppercorns against different instars of an Indian strain of dengue fever mosquito, Aedes aegypti L. (Diptera: Culicidae). Parasitol Res 107(4):901-907. https://doi.org/10.1007/s00436-010-1948-1

33. Finlayson C, Saingamsook J, Somboon P (2015) A simple and affordable membrane-feeding method for Aedes aegpyti and Anopheles minimus (Diptera: Culicidae). Acta Trop 152:245-251. https://doi.org/10.1016/j.actatropica.2015.09.026

34. Zaim M/WHOPES (2005) https://www.who.int/whopes/resou rces/who_cds_whopes_gcdpp_2005.13/en/

35. Coelho JS, Santos NDL, Napoleao TH, Gomes FS, Ferreira RS, Zingali RB, Coelho LCBB, Leite SP, Navarro DMAF, Paiva PMG (2009) Effect of Moringa oleifera lectin on development and mortality of Aedes aegypti larvae. Chemosphere 77:934-938. https://doi. org/10.1016/j.ecoenv.2017.01.026

36. Napoleão TH, Pontual EV, de Albuquerque TL, de Lima Santos ND, Sá RA, Coelho LCCB et al (2012) Effect of Myracrodruon urundeuva leaf lectin on survival and digestive enzymes of 
Aedes aegypti larvae. Parasitol Res 110(2):609-616. https://doi. org/10.1007/s00436-011-2529-7

37. Bradford MM (1976) A rapid and sensitive method for the quantitation of microgram quantities of protein utilizing the principle of protein-dye binding. Anal Biochem 72(1-2):248-254. https:// doi.org/10.1016/0003-2697(76)90527-3

38. Ellman GL, Courtney KD Jr, Andres V, Featherstone RM (1961) A new and rapid colorimetric determination of acetylcholinesterase activity. Biochem Pharmacol 7(2):88-95. https://doi. org/10.1016/0006-2952(61)90145-9

39. Ikezawa H, Taguchi R (1981) Phosphatidylinositol-specific phospholipase $\mathrm{C}$ from Bacillus cereus and Bacillus thuringiensis. Methods Enzymol 71:731-741. https://doi.org/10.1016/00766879(81)71086-3

40. Vontas JG, Enayati AA, Small GJ, Hemingway J (2000) A simple biochemical assay for glutathione S-transferase activity and its possible field application for screening glutathione S-transferase-based insecticide resistance. Pestic Biochem Physiol 68(3):184-192. https://doi.org/10.1006/pest.2000.2512

41. Habig WH, Pabst MJ, Jakoby WB (1974) Glutathione S-transferases the first enzymatic step in mercapturic acid formation. J Biol Chem 249(22):7130-7139

42. Rajasekharreddy P, Rani PU (2014) Biofabrication of Ag nanoparticles using Sterculia foetida L. seed extract and their toxic potential against mosquito vectors and HeLa cancer cells. Mater Sci Eng C 39:203-212. https://doi.org/10.1016/j.msec.2014.03.003

43. Gupta S, Preet $S$ (2012) Protocol optimization for genomic DNA extraction and RAPD-PCR in mosquito larvae (Diptera: Culicidae). Ann Biol Res 3(3):1553-1561

44. Glasel JA (1995) Validity of nucleic acid purities monitored by 260nm/280nm absorbance ratios. Biotechniques 18(1):62-63

45. Rajesh WR, Jaya RL, Niranjan SK, Vijay DM, Sahebrao BK (2009) Phytosynthesis of Silver Nanoparticle Using Gliricidia sepium (Jacq.). Curr Nanosci 5:117-122. https://doi.org/10.2174/15734 1309787314674

46. Zak AK, Majid WHA, Mahmoudian MR, Darroudi M, Youse R (2013) Starch-stabilized synthesis of $\mathrm{ZnO}$ nanopowders at low temperature and optical properties study. Adv Powder Technol 24:618-624. https://doi.org/10.1016/j.apt.2012.11.008

47. Zak AK, Abrishami ME, Majid WA, Yousefi R, Hosseini SM (2011) Effects of annealing temperature on some structural and optical properties of $\mathrm{ZnO}$ nanoparticles prepared by a modified solgel combustion method. Ceram Int 37(1):393-398. https://doi. org/10.1016/j.ceramint.2010.08.017

48. Mahamuni PP, Patil PM, Dhanavade MJ, Badiger MV, Shadija PG, Lokhande AC, Bohara RA (2019) Synthesis and characterization of zinc oxide nanoparticles by using polyol chemistry for their antimicrobial and antibiofilm activity. Biochem Biophys Rep 17:71-80. https://doi.org/10.1016/j.bbrep.2018.11.007

49. Ishwarya R, Vaseeharan B, Kalyani S, Banumathi B, Govindarajan K, Alharbi NS, Kadaikunnan S, Al-anbr MN, Khaled JM, Benelli G (2018) Facile green synthesis of zinc oxide nanoparticles using Ulva lactuca seaweed extract and evaluation of their photocatalytic, antibiofilm and insecticidal activity. J Photochem Photobiol B 178:249-258. https://doi.org/10.1016/j.jphotobiol .2017 .11 .006

50. Senthilkumar $N$, NandhaKumar E, Priya $P$, Soni D, Vimalan $M$, Potheher IV (2017) Synthesis of ZnO nanoparticles using leaf extract of Tectona grandis (L.) and their anti-bacterial, antiarthritic, anti-oxidant and in vitro cytotoxicity activities. New J Chem 41:10347-10356. https://doi.org/10.1039/C7NJ02664A

51. Davis K, Yarbrough R, Froeschle M, White J, Rathnayake H (2019) Band gap engineered zinc oxide nanostructures via a sol-gel synthesis of solvent driven shape-controlled crystal growth. RSC Adv 9(26):14638-14648. https://doi.org/10.1039/C9RA02091H
52. Awwad AM, Salem NM, Abdeen AO (2012) Biosynthesis of Silver nanoparticles using Olea europaea leaves extract and its antibacterial activity. Nanosci Nanotechnol 2(6):164-170. https:// doi.org/10.5923/j.nn.20120206.03

53. Zhang G, Du M, Li Q, Li X, Huang J, Jiang X, Sun D (2013) Green synthesis of $\mathrm{Au}-\mathrm{Ag}$ alloy nanoparticles using Cacumen platycladi extract. Rsc Adv 3(6):1878-1884. https://doi.org/10.1039/C2RA2 $2442 \mathrm{~A}$

54. Al RN, Al-Haidari KS (2016) Environmental friendly synthesis of silver nanoparticles using leaf extract of Mureira Tree (Azadirachta indica) cultivated in Iraq and efficacy the antimicrobial activity. J Nat Sci Res 6(4):2224-3186

55. Shankar SS, Ahmad A, Sastry M (2003) Geranium leaf assisted biosynthesis of silver nanoparticles. Biotechnol Prog 19(6):16271631. https://doi.org/10.1021/bp034070w

56. Bala N, Saha S, Chakraborty M, Maiti M, Das S, Basub R, Nandy P (2015) Green synthesis of zinc oxide nanoparticles using Hibiscus subdariffa leaf extract: effect of temperature on synthesis, anti-bacterial activity and anti-diabetic activity. RSC Adv 5:4993-5003. https://doi.org/10.1039/C4RA12784F

57. Xiong G, Pal U, Serrano JG, Ucer KB, Williams RT (2006) Photoluminesence and FTIR study of $\mathrm{ZnO}$ nanoparticles: the impurity and defect perspective. Phys Stat Solidi C 3(10):3577-3581. https://doi.org/10.1002/pssc.200672164

58. Yuvakkumar R, Suresh J, Saravanakumar B, Nathanael AJ, Hong SI, Rajendran V (2015) Rambutan peels promoted biomimetic synthesis of bioinspired zinc oxide nanochains for biomedical applications. Spectrochim Acta A 137:250-258. https://doi. org/10.1016/j.saa.2014.08.022

59. Ramesh AV, Pavankumar Y, Lavakusa B (2017) A facile green synthesis of $\mathrm{ZnO}$ nanorods using leaf extract of Ficus hispida L. Int J Eng Appl Sci Technol 2(4):2143

60. Narendhran S, Sivaraj R (2016) Biogenic ZnO nanoparticles synthesized using $L$. aculeata leaf extract and their antifungal activity against plant fungal pathogens. Bull Mater Sci 39:1-5. https ://doi.org/10.1007/s12034-015-1136-0

61. Vanathi P, Rajiv P, Narendhran S, Rajeshwari S, Rahman PKSM, Venckatesh R (2014) Biosynthesis and characterization of phyto mediated zinc oxide nanoparticles: a green chemistry approach. Mater Lett 134:13-15. https://doi.org/10.1016/j.matle t.2014.07.029

62. Elango G, Roopan SM, Dhamodaran KI, Elumalai K, Al-dhabi NA, Arasu MV (2016) Spectroscopic investigation of biosynthesized nickel nanoparticles and its larvicidal, pesticidal activities. J Photochem Photobiol B 162:162-167. https://doi.org/10.1016/j. jphotobiol.2016.06.045

63. Zheng J, Nagashima K, Parmiter D, De Cruz J, Patri AK (2011) SEM X-Ray microanalysis of nanoparticles present in tissue or cultured cell thin sections. Methods Mol Biol 697:93-99. https ://doi.org/10.1016/j.chemosphere.2009.08.022

64. Kim SJ, Park DW (2009) Preparation of ZnO nanopowders by thermal plasma and characterization of photo-catalytic property. Appl Surf Sci 255:5363-5367. https://doi.org/10.1016/j. apsusc.2008.10.028

65. Dobrucka R, Długaszewska J (2016) Biosynthesis and antibacterial activity of $\mathrm{ZnO}$ nanoparticles using Trifolium pratense flower extract. Saudi J Biol Sci 23(4):517-523. https://doi.org/10.1016/j. sjbs.2015.05.016

66. Ashokan AP, Paulpandi M, Dinesh D, Murugan K, Vadivalagan C, Benelli G (2017) Toxicity on dengue mosquito vectors through Myristica fragrans synthesized zinc oxide nanorods, and their cytotoxic effects on liver cancer cells (HepG2). J Clust Sci 28(1):205-226. https://doi.org/10.1007/s10876-016-1075-y

67. Chennimalai M, Do JY, Kang M, Senthil TS (2019) A facile green approach of ZnO NRs synthesized via Ricinus communis $L$ leaf 
extract for Biological activities. Mater Sci Eng C 103:109844. https://doi.org/10.1016/j.msec.2019.109844

68. Kavithaa K, Paulpandi M, Ponraj T, Murugan K, Sumathi S (2016) Induction of intrinsic apoptotic pathway in human breast cancer (MCF-7) cells through facile biosynthesized zinc oxide nanorods. Karbala Int J Mod Sci 2(1):46-55. https://doi.org/10.1016/j.kijom s.2016.01.002

69. Saeb A, Alshammari AS, Al-Brahim H, Al-Rubeaan KA (2014) Production of silver nanoparticles with strong and stable antimicrobial activity against highly pathogenic and multidrug resistant bacteria. Sci World J. https://doi.org/10.1155/2014/704708

70. Ali MS, Ravikumar S, Beula JM (2012) Spatial and temporal distribution of mosquito larvicidal compounds in mangroves. Asian Pac JTrop Dis 2(5):401-404. https://doi.org/10.1016/S2222 -1808(12)60087-5

71. Murugan $\mathrm{K}$, Anitha J, Suresh U, Rajaganesh R, Panneerselvam C, Tseng LC, Kalimuthu K, Alsalhi MS, Devanesan S, Nicoletti M, Sarkar SK (2017) Chitosan-fabricated Ag nanoparticles and larvivorous fishes: a novel route to control the coastal malaria vector Anopheles sundaicus? Hydrobiologia 797(1):335-350. https ://doi.org/10.1007/s10750-017-3196-1

72. Abinaya $M$, Vaseeharan B, Divya $M$, Sharmili A, Govindarajan $M$, Alharbi NS, Kadaikunnan S, Khaled JM, Benelli G (2018) Bacterial exopolysaccharide (EPS)-coated $\mathrm{ZnO}$ nanoparticles showed high antibiofilm activity and larvicidal toxicity against malaria and Zika virus vectors. J Trace Elem Med Biol 45:93-103. https ://doi.org/10.1016/j.jtemb.2017.10.002

73. Fournier D (2005) Mutations of acetylcholinesterase which confer insecticide resistance in insect populations. Chem Biol Interact 157-158:257-261. https://doi.org/10.1016/j.cbi.2005.10.040

74. Gupta VK, Pal R, Siddiqi NJ, Sharma B (2015) Acetylcholinesterase from human erythrocytes as a surrogate biomarker of lead induced neurotoxicity. Enzym Res 2015:1-7. https://doi. org/10.1155/2015/370705

75. Suganthy N, Pandian SK, Devi KP (2009) Cholinesterase inhibitory effects of Rhizophora lamarckii, Avicennia officinalis, Sesuvium portulacastrum and Suaeda monica: mangroves inhabiting an Indian coastal area (Vellar Estuary). J Enzym Inhib Med Chem 24(3):702-707. https://doi.org/10.1080/14756360802334719

76. Koodalingam A, Mullainadhan P, Arumugam M (2011) Effects of extract of soapnut Sapindus emarginatus on esterases and phosphatases of the vector mosquito, Aedes aegypti (Diptera: Culicidae). Acta Trop 118(1):27-36. https://doi.org/10.1016/j. actatropica.2011.01.003

77. Wang Z, Zhao J, Li F, Gao D, Xing B (2009) Adsorption and inhibition of acetylcholinesterase by different nanoparticles.
Chemosphere 77:67-73. https://doi.org/10.1016/j.chemospher e.2009.05.015

78. Wang Z, Zhang K, Zhao J, Liu X, Xing B (2010) Adsorption and inhibition of butyrylcholinesterase by different engineered nanoparticles. Chemosphere 79:86-92. https://doi.org/10.1016/j. chemosphere.2009.12.051

79. Fouad H, Hongjie L, Hosni D, Wei J, Abbas G, Ga'alJianchu HM (2018) Controlling Aedes albopictus and Culex pipiens pallens using silver nanoparticles synthesized from aqueous extract of Cassia fistula fruit pulp and its mode of action. Artif Cells Nanomed Biotechnol 46(3):558-567. https://doi. org/10.1080/21691401.2017.1329739

80. Solairaj D, Rameshthangam P (2017) Silver nanoparticle embedded a-chitin nanocomposite for enhanced antimicrobial and mosquito larvicidal activity. J Polym Environ 25:435-452. https ://doi.org/10.1007/s10924-016-0822-3

81. Lu FC, Kacew S (2002) Lus basic toxicology: fundamentals, targets organ and risk assesment, 4th edn. CRC Press, Boca Raton, pp 386-392

82. Kim IH, Suzuki R, Hitotsuyanagi Y, Takeya K (2003) Three novel quassinoids, javanicolides $A$ and $B$, and javanicoside $A$, from seeds of Brucea javanica. Tetrahedron 59(50):9985-9989. https ://doi.org/10.1016/j.tet.2003.10.048

83. Vanhaelen N, Haubruge E, Lognay G, Francis F (2001) Hoverfly glutathione S-transferases and effect of Brassicaceae secondary metabolites. Pestic Biochem Physiol 71(3):170-177. https://doi. org/10.1006/pest.2001.2573

84. Parkes TL, Hilliker AJ, Phillips JP (1993) Genetic and biochemical analysis of glutathione-S-transferase in the oxygen defense system of Drosophila melanogaster. Genome 36:1007-1014. https ://doi.org/10.1139/g93-134

85. Giordano G, Afsharinejad Z, Guizzetti M, Vitalone A, Kavanagh TJ, Costa LG (2007) Organophosphorus insecticides chlorpyrifos and diazinon and oxidative stress in neuronal cells in a genetic model of glutathione deficiency. Toxicol Appl Pharmacol 219:181-189. https://doi.org/10.1016/j.taap.2006.09.016

86. Vontas JG, Graham J, Hemingway J (2001) Glutathione S-transferases as antioxidant defence agents confer pyrethroid resistance in Nilaparvata lugens. Biochem J 357:65-72. https://doi. org/10.1042/bj3570065

87. Vorbrodt A (1959) The role of phosphatase in intracellular metabolism. Postepy Hig Med Dosw 13:200-206

Publisher's Note Springer Nature remains neutral with regard to jurisdictional claims in published maps and institutional affiliations. 